\title{
Diversity and quantity of ammonia-oxidizing Archaea and Bacteria in sediment of the Pearl River Estuary, China
}

\author{
Tao Jin • Tong Zhang $\cdot$ Lin Ye $\cdot$ On On Lee • \\ Yue Him Wong • Pei Yuan Qian
}

Received: 15 November 2010 /Revised: 29 December 2010 /Accepted: 30 December 2010 /Published online: 1 February 2011

(C) The Author(s) 2011. This article is published with open access at Springerlink.com

\begin{abstract}
The diversity and abundance of ammoniaoxidizing archaea (AOA) and ammonia-oxidizing bacteria (AOB) in the sediment of the Pearl River Estuary were investigated by cloning and quantitative real-time polymerase chain reaction (qPCR). From one sediment sample S16, 36 AOA OTUs ( $3 \%$ cutoff) were obtained from three clone libraries constructed using three primer sets for amoA gene. Among the 36 OTUs, six were shared by all three clone libraries, two appeared in two clone libraries, and the other 28 were only recovered in one of the libraries. For AOB, only seven OTUs (based on 16S rRNA gene) and eight OTUs (based on amoA gene) were obtained, showing lower diversity than AOA. The qPCR results revealed that AOA amoA gene copy numbers ranged from $9.6 \times 10^{6}$ to $5.1 \times 10^{7}$ copies per gram of sediment and $\mathrm{AOB}$ amo $\mathrm{A}$ gene ranged from $9.5 \times 10^{4}$ to $6.2 \times 10^{5}$ copies per gram of sediment, indicating that the dominant ammonia-oxidizing microorganisms in the sediment of the Pearl River Estuary were AOA. The terminal restriction fragment length polymorphism results showed that the relative abundance
\end{abstract}

Electronic supplementary material The online version of this article (doi:10.1007/s00253-011-3107-8) contains supplementary material, which is available to authorized users.

T. Jin $\cdot$ T. Zhang $(\bowtie) \cdot$ L. Ye

Environmental Biotechnology Laboratory,

The University of Hong Kong,

Pokfulam Road,

Hong Kong, Hong Kong

e-mail: zhangt@hkucc.hku.hk

O. O. Lee $\cdot$ Y. H. Wong $\cdot$ P. Y. Qian

Department of Biology,

The Hong Kong University of Science and Technology,

Clear Water Bay, Hong Kong of AOB species in the sediment samples of different salinity were significantly different, indicating that salinity might be a key factor shaping the AOB community composition.

Keywords Ammonia monooxygenase $\alpha$-subunit (amoA) gene $\cdot$ Ammonia-oxidizing archaea (AOA) - Ammoniaoxidizing bacteria $(\mathrm{AOB}) \cdot \mathrm{T}-\mathrm{RFLP} \cdot \mathrm{qPCR}$

\section{Introduction}

Microorganisms in marine sediments contribute significantly to global cycles of organic and inorganic matters (Whitman et al. 1998), including nitrogen cycle. Biological nitrogen fixation is the largest source of nitrogen to the ocean, whereas anoxic/anaerobic microbial processes are responsible for nitrogen losses (Gruber and Sarmiento 1997). These two processes are connected by nitrification, the microbial oxidation of ammonia $\left(\mathrm{NH}_{3}\right)$ to nitrate $\left(\mathrm{NO}_{3}{ }^{-}\right)$via nitrite $\left(\mathrm{NO}_{2}{ }^{-}\right)$. Coupled nitrification/ denitrification can remove a substantial percentage (10 80\%) of anthropogenic nitrogen pollution in estuaries (Seitzinger 1988). Previous studies have focused on the ammonia-oxidizing bacteria (AOB), mainly targeting both the 16S rRNA gene and amoA gene which encodes $\alpha$ subunit of the ammonia monooxygenase (AMO) (Purkhold et al. 2000). All the known AOB are phylogenetically restricted to the $\beta$ - and $\gamma$-proteobacteria. Recently, it was discovered that many archaea in the phylum Crenarchaeota are also capable of performing ammonia oxidation like AOB (Könneke et al. 2005; Venter et al. 2004). Both ammonia oxidizing archaea (AOA) and AOB contains the key enzyme AMO which is composed of three subunits 
encoded by genes of amo A, amoB, and amoC (Klotz et al. 1997 ) and responsible for the conversion of ammonia to hydroxylamine. By performing the key first step in nitrification, both $\mathrm{AOA}$ and $\mathrm{AOB}$ play an important role in the global nitrogen cycle.

However, estuaries and their intertidal sediments experience large fluctuations in various hydrological and chemical conditions. Therefore, the communities of AOA and AOB might show dynamic changes in response to environmental factors. A few studies demonstrated that diverse AOA/AOB phylotypes and distinct $\mathrm{AOA} / \mathrm{AOB}$ communities existed in different marine environments both on a large geographical scale and in local estuarine gradients (Beman and Francis 2006; Francis et al. 2005; Sahan and Muyzer 2008). Studies already showed that archaeal amoA gene copy numbers were about 10 to 1,000 times of those of bacterial amoA in the North Sea and North Atlantic (Wuchter et al. 2006), indicating dominance of AOA in ocean environments. So far, most of the studies on AOA and $\mathrm{AOB}$ in marine water and sediment focused on the coast of the East Pacific Ocean and Atlantic. The diversity and spatial distribution of AOA and AOB are still unknown in other ocean areas of the world, including the Pearl River Estuary.

The Pearl River, the third largest river in China, stretching for 2,214 $\mathrm{km}$ and draining an area of $452,000 \mathrm{~km}^{2}$, flows into the Pearl River Estuary through eight entrances. The Pearl River Estuary is located in the subtropical region in Guangdong Province, Southern China. It represents one of the most important and complex ecosystems linking the highly developing land area and the South China Sea. In recent years, the Pearl River has a high load of anthropogenic nutrients from increased agricultural activities, fish dike farming, and wastewater runoff due to the increase in population and economic development in Southern China and the Pearl River Delta region (Huang et al. 2003). Previous study also showed high nitrification rates in summer (ammonia oxidation rate $\sim 1.5-33.1 \mu \mathrm{mol} \mathrm{NL}{ }^{-1} \mathrm{day}^{-1}$, nitrite oxidation rate $\sim 0.6-32.0 \mu \mathrm{mol} \mathrm{NL}{ }^{-1} \mathrm{day}^{-1}$ ) (Dai et al. 2008). However, the microorganisms responsible for the nitrification in this area are little known.

In this study, five sediment samples were collected in the Pearl River Estuary from different sites along the salinity gradient (Fig. 1). The diversity of AOA and AOB were revealed based on clone libraries. Quantification of AOA and AOB were performed using quantitative PCR (qPCR). For AOA, three primer sets of amoA gene were selected for construction of clone libraries and qPCR to evaluate the specificity and universality of these primers. Terminal restriction fragment length polymorphism (T-RFLP) was used to analyze the spatial distribution of different AOB populations.

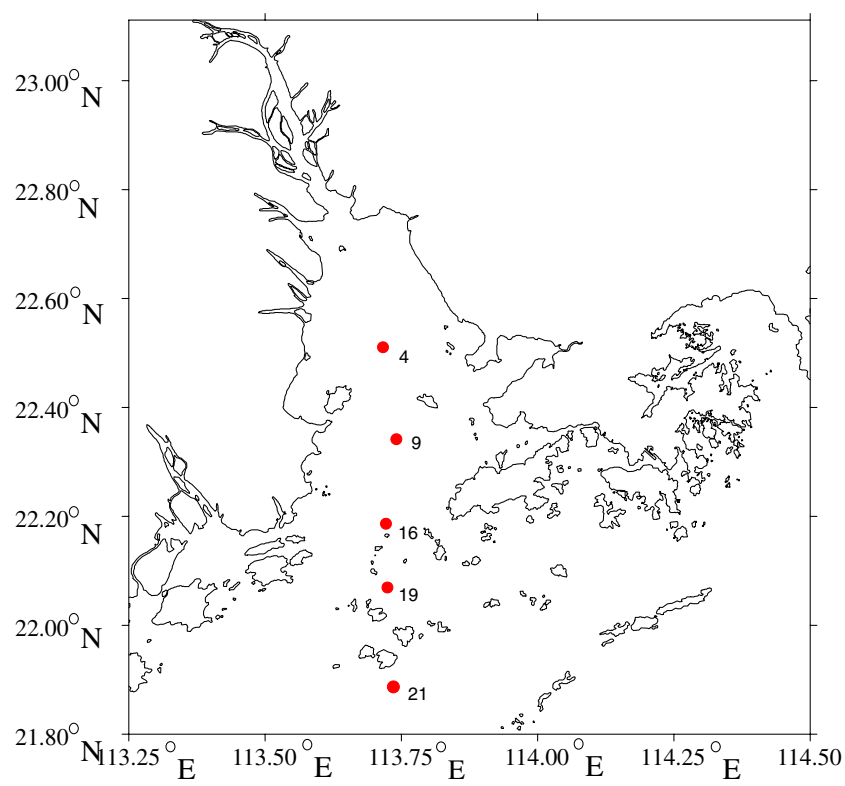

Fig. 1 Map showing the sampling locations in this study. Surface sediment samples were collected from sites 4, 9, 16, 19, and 21 along a transect from the Pearl River Estuary to the South China Sea in the

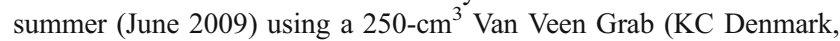
Denmark). Upon collection of the sediment samples, about $2 \mathrm{~kg}$ of sediment were transferred to sterile plastic bags and frozen at $-80^{\circ} \mathrm{C}$. Frozen sediment samples were then transferred back to the laboratory with dry ice

\section{Materials and methods}

Sample collection and chemical analyses

Surface sediment samples were collected from five locations along a transect from the Pearl River Estuary to the South China Sea in the summer (June 2009; Fig. 1) using a $250-\mathrm{cm}^{3}$ Van Veen Grab (KC Denmark, Denmark). Upon collection of the sediment samples, about $2 \mathrm{~kg}$ of sediment were transferred to sterile plastic bags and frozen at $-80^{\circ} \mathrm{C}$. Frozen sediment samples were then transferred back to the laboratory with dry ice. Except for the depth and temperature which were measured on site, other parameters were measured using the pore water of the sediments. Concentrations of ammonium, nitrite, and nitrate were measured according to the Standard Methods (APHA 2005) by Nesslerization method, colorimetric method, and ultraviolet spectrophotometric screening method, respectively. Table S1 showed all physical and chemical properties of the Pearl River Estuary sediments.

DNA extraction, PCR, and cloning

Genomic DNA was extracted from $10 \mathrm{~g}$ of sediment sample using PowerMax ${ }^{\mathrm{TM}}$ Soil DNA Isolation Kit (Mo Bio Laboratories Inc., USA) and further purified using the TaKaRa Agarose Gel DNA Purification Kit (TaKaRa, 
China) according to manufacturer's protocol. The concentration of DNA was determined by NanoDrop ${ }^{\circledR}$ Spectrophotometer ND-1000 (Thermo Fisher Scientific, USA). The primers used were listed in Table 1. For archaeal amoA gene, the PCR was performed in a total volume of $25 \mu \mathrm{L}$ containing $20 \mathrm{ng}$ of DNA template, $1 \mathrm{U}$ of AmpliTaq ${ }^{\circledR}$ DNA polymerase (Applied Biosystem, Branchburg, USA), $0.2 \mu \mathrm{M}$ of each primer, and $12.5 \mu \mathrm{L}$ FailSafe $^{\mathrm{TM}} \mathrm{PCR}$ Premix F (EPICENTRE Biotechnologies, Madison, USA). For AOB 16S rRNA and amoA genes, PCR was performed in a total volume of $25 \mu \mathrm{L}$ containing $20 \mathrm{ng}$ of DNA template, $2.5 \mu \mathrm{L}$ buffer, $250 \mathrm{mM}$ of each deoxyribonucleotide triphosphate, $1 \mathrm{U}$ of ExTaq (TaKaRa) DNA polymerase, and $0.2 \mu \mathrm{M}$ of each primer. The major cycling program for each primer set was listed in Table 1. The presence and sizes of the PCR amplification products were determined by agarose $(1 \%)$ gel electrophoresis.

PCR products were purified by using Quick-spin ${ }^{\mathrm{TM}} \mathrm{PCR}$ Products Purification Kit (iNtRON Biotechnology, Seongnam-Si, Korea). Then, the PCR products were cloned using InsT/Aclone ${ }^{\mathrm{TM}}$ PCR Cloning Kit (Fermentas, Vilnius, Lithuania). White colonies were selected for insert screening by using PCR with primers M13F and M13R. The sequencing of selected clones was performed by using M13F primer on ABI 3730xl capillary sequencers (PE Applied Biosystems, Foster City, USA).

The estimation of diversity index in each library was determined using the ESTIMATES V8.0 (http://viceroy.eeb. uconn.edu/estimates). The Chao 1 estimator of species richness was calculated after 1,000 randomizations of sampling, without replacement. The percentage of coverage was calculated using Good's method (Good 1953). Operational taxonomic unit (OTU) in this study was defined as a sequence group in which sequences differed by $\leq 3 \%$.

\section{Phylogenetic analysis}

The nucleotide sequences were compared with those from the GenBank using BLASTn in the National Center for the Biotechnology Information (NCBI) server (http://www. ncbi.nlm.nih.gov). The sequences in this study and the reference sequences retrieved from the GenBank were aligned by ARB (http://www.arb-home.de) (Ludwig et al. 2004) to construct phylogenetic trees using the neighborjoining method (based on Jukes-Cantor-corrected distance). Bootstrap value was calculated based on 1,000 replications.

\section{Quantitative PCR}

Quantitative PCR was performed using an iCycler IQ System (Bio-Rad, Hercules, USA), three replicates for each sample. For AOA amoA gene, qPCR was conducted in a total volume of $30 \mu \mathrm{L}$ containing $15 \mu \mathrm{L}$ of FailSafe ${ }^{\mathrm{TM}}$ PCR Premix F, $5 \mu \mathrm{L}$ of DNA template, $0.2 \mu \mathrm{M}$ of each primer, $1.5 \mathrm{U}$ of AmpliTaq ${ }^{\circledR}$ DNA polymerase, $15 \mathrm{mM} \mathrm{MgCl}_{2}$, and $0.5 \times$ SYBR $^{\circledR}$ Green I (Invitrogen, Eugene, USA). For AOB $16 \mathrm{~S}$ rRNA and amoA genes, PCR was performed in a total volume of $30 \mu \mathrm{L}$ containing $15 \mu \mathrm{L}$ of $\mathrm{iQ}^{\mathrm{TM}} \mathrm{SYBR}^{\circledR}$ Green

Table 1 Primers and PCR conditions. Genomic DNA was extracted from $10 \mathrm{~g}$ of sediment sample using PowerMax ${ }^{\mathrm{TM}}$ Soil DNA Isolation Kit (Mo Bio Laboratories Inc, USA) and further purified using the

TaKaRa Agarose Gel DNA Purification Kit (TaKaRa, China) according to manufacturer's protocol

\begin{tabular}{|c|c|c|c|c|c|c|}
\hline Target gene & & Primer & Sequence $\left(5^{\prime}-3^{\prime}\right)$ & $\begin{array}{l}\text { Length of } \\
\text { product }(\mathrm{bp})\end{array}$ & PCR program & Reference \\
\hline \multirow[t]{6}{*}{ amoA } & \multirow[t]{4}{*}{$\mathrm{AOA}$} & cren amo_F (I) ${ }^{\mathrm{a}}$ & $\begin{array}{l}\text { ATGGTCTGGCTAA } \\
\text { GACGMTGTA }\end{array}$ & 632 & \multirow[t]{4}{*}{$\begin{array}{l}\left(94^{\circ} \mathrm{C}, 45 \mathrm{~s} ; 55^{\circ} \mathrm{C}, 45 \mathrm{~s}\right. \\
\left.\quad 72^{\circ} \mathrm{C}, 45 \mathrm{~s}\right) \times 35\end{array}$} & Hallam et al. 2006 \\
\hline & & Arch-amoAF (II) & $\begin{array}{l}\text { STAATGGTCTGGC } \\
\text { TTAGACG }\end{array}$ & 635 & & Francis et al. 2005 \\
\hline & & Arch_amoA_F (III) & $\begin{array}{l}\text { AATGGTCTGGSTT } \\
\text { AGAMG }\end{array}$ & \multirow[t]{2}{*}{633} & & $\begin{array}{l}\text { De la Torre et al. } \\
2008\end{array}$ \\
\hline & & Arch-amoAR & $\begin{array}{l}\text { GCGGCCATCCATC } \\
\text { TGTATGT }\end{array}$ & & & Francis et al. 2005 \\
\hline & \multirow[t]{2}{*}{$\mathrm{AOB}$} & amoA-1F & $\begin{array}{l}\text { GGGGTTTCTACTG } \\
\text { GTGGT }\end{array}$ & \multirow[t]{2}{*}{491} & \multirow[t]{2}{*}{$\begin{array}{l}\left(94^{\circ} \mathrm{C}, 45 \mathrm{~s} ; 55^{\circ} \mathrm{C}, 45 \mathrm{~s}\right. \\
\left.\quad 72^{\circ} \mathrm{C}, 45 \mathrm{~s}\right) \times 35\end{array}$} & \multirow[t]{2}{*}{$\begin{array}{l}\text { Rotthauwe et al. } \\
1997\end{array}$} \\
\hline & & amoA-2 $\mathrm{R}^{\mathrm{a}}$ & $\begin{array}{l}\text { CCCCTCKGSAAAG } \\
\text { ССТTCTTC }\end{array}$ & & & \\
\hline \multirow[t]{2}{*}{$16 \mathrm{~S}$ rRNA } & \multirow[t]{2}{*}{$\mathrm{AOB}$} & NitA & $\begin{array}{l}\text { CTTAAGTGGGGAA } \\
\text { TAACGCATCG }\end{array}$ & \multirow[t]{2}{*}{518} & \multirow[t]{2}{*}{$\begin{array}{l}\left(94^{\circ} \mathrm{C}, 45 \mathrm{~s} ; 57^{\circ} \mathrm{C}, 45 \mathrm{~s}\right. \\
\left.\quad 72^{\circ} \mathrm{C}, 45 \mathrm{~s}\right) \times 35\end{array}$} & $\begin{array}{l}\text { Voytek and Ward } \\
1995\end{array}$ \\
\hline & & СТO654r & $\begin{array}{l}\text { CTAGCYTTGTAGTT } \\
\text { TCAAACGC }\end{array}$ & & & $\begin{array}{l}\text { Kowalchuck et al. } \\
1997\end{array}$ \\
\hline
\end{tabular}

The concentration of DNA was determined by NanoDrop ${ }^{\circledR}$ Spectrophotometer ND-1000 (Thermo Fisher Scientific, USA). PCR was performed using FailSafe ${ }^{\mathrm{TM}}$ PCR Premix F (EPICENTRE Biotechnologies, Madison, USA) following the cycling program for each primer set listed here

${ }^{\text {a }}$ Primers used for T-RFLP analysis were labeled by Hex 
Super Mix (Bio-Rad, Hercules, USA), $5 \mu \mathrm{L}$ of DNA template, and $0.2 \mu \mathrm{M}$ of each primer. The qPCR thermocycling steps were set as follows: $95^{\circ} \mathrm{C}$ for $4 \mathrm{~min}$ and 45 cycles at $95^{\circ} \mathrm{C}$ for $45 \mathrm{~s}, 55^{\circ} \mathrm{C}$ for $45 \mathrm{~s}$, and $72^{\circ} \mathrm{C}$ for $45 \mathrm{~s}$. Cycling was completed by a final elongation step at $72^{\circ} \mathrm{C}$ for $10 \mathrm{~min}$. The negative control containing no DNA was subjected to the same procedure to exclude or detect any possible contamination. After qPCR assay, the specificity of amplification was verified by melting curve analysis and checking with agarose gel electrophoresis.

\section{T-RFLP analysis}

For T-RFLP, PCR was performed by using fluorescently labeled primer amoA-2R-Hex for AOB. PCR conditions were as the same as those described above for clone library construction. AluI was selected to digest PCR products of $\mathrm{AOB}$ amoA gene. The digestion mixture, containing $17 \mu \mathrm{L}$ of purified PCR product (about 200 ng DNA), $2 \mu \mathrm{L}$ of buffer, and $1 \mu \mathrm{L}$ of restriction enzyme $(10 \mathrm{U} / \mu \mathrm{L})$, was incubated at $37^{\circ} \mathrm{C}$ for $5 \mathrm{~h}$. The fluorescently labeled T-RFs were run though an ABI 3730xl capillary sequencers in the GeneScan mode. T-RFLP data was analyzed using GeneMarker V1.6 (SoftGenetics LLC, Pennsylvania, USA). Because of the detection range of internal marker GS500, T-RFs smaller than $50 \mathrm{bp}$ and larger than $500 \mathrm{bp}$ were excluded from further analysis. The peaks were first selected by default parameters setting of the software GeneMarker with the threshold cutoff of peak intensity of 100. The relative abundance of each T-RF was then determined by calculating the ratio between the area of each peak and the total area of all peaks in one sample. The peaks with relative abundance less than $1 \%$ were neglected in this study.

\section{Accession number}

The sequences reported in this study were deposited in GenBank under accession numbers GU988755GU988900.

\section{Results}

Physical and chemical properties of the sediment samples

Table S1 (supporting information) summarized the physical and chemical properties of the five sediment samples. It shows that the salinity of these five samples differ significantly, increasing from $5.6 \mathrm{psu}$ at site $\mathrm{S} 4$ to 24.6 psu at site S21, while other parameters are relatively stable.
Diversity of AOA amoA gene sequences

Archaeal amoA clone libraries were generated for the sediment sample S16 by using three primer sets (Table 1). A total of 145 clones were sequenced and grouped into 36 OTUs. In details, three clone libraries (A1, A2, and A3) recovered 19,16, and 15 OTUs using primer sets I, II, and III, respectively (Table S2). Six OTUs (Fig. 2a, OTU1-6) were shared by the three clone libraries and accounted for $57 \%, 64 \%$, and $70 \%$ of total clones in the three libraries, respectively. Two OTUs (Fig. 2a, OTU7 and OTU8) appeared in two clone libraries. The other 28 OTUs were only recovered in one of the three libraries.

Diversity of AOB $16 \mathrm{~S}$ rRNA and amoA gene sequences

For AOB 16S rRNA gene clone library, as shown in Fig. S1, 26 clones were sequenced and grouped into seven OTUs, i.e., one OTU in the genus Nitrosospira and six OTUs in the genus Nitrosomonas. Similarly, 26 AOB amoA gene sequences were generated from another clone library and grouped into eight OTUs (Fig. 2b): three OTUs in the genus Nitrosospira and five OTUs in the genus Nitrosomonas. No $\gamma$-AOB sequences were found in the amo $\mathrm{A}$ gene clone library indicating that the major $\mathrm{AOB}$ species in the samples were $\beta$-AOB.

\section{Quantification of AOA and AOB}

To quantify the AOA abundance, three primer sets of AOA amoA gene were used for qPCR. The results showed that qPCR could be successfully conducted by using the primer sets I and III. The qPCR results showed that the AOA abundance was significantly different by using two primer sets for the samples S9, S16, S19, and S21. Generally, as shown in Fig. 3, the AOA abundance calculated from qPCR using primer set I was about 10 times higher than that using primer set III. Only for the sample S4, two primer sets resulted in the same level of AOA abundance.

AOA amoA gene copy numbers based on qPCR by using primer set I ranged from $6.8 \times 10^{3}$ to $2.2 \times 10^{4}$ copies per nanogram DNA and from $9.6 \times 10^{6}$ to $5.1 \times 10^{7}$ copies per gram of sediment (wet weight). Over all, there was no significantly difference among five sediment samples considering the variation of qPCR itself.

AOB abundance was quantified by qPCR using both AOB 16S rRNA and amoA genes. As shown in Fig. 3, AOB 16S rRNA gene ranged from 15 to 126 copies per nanogram DNA and $2.7 \times 10^{4}$ to $1.4 \times 10^{5}$ copies per gram of sediment. Similarly, AOB amoA gene resulted in 67 to 333 copies per nanogram DNA and $9.5 \times 10^{4}$ to $6.2 \times 10^{5}$ copies per gram of sediment. If assuming that there is one 
Fig. 2 Phylogenetic trees of AOA (a) and AOB (b). The neighbor-joining trees were constructed using ARB based on Jukes-Cantor-corrected DNA distances, showing the phylogenetic affiliation of amoA gene sequences from the Pearl River Estuary sediment S16 (printed in bold) and from other environmental samples or pure strain retrieved from the GeneBank. In (a), except for the singletons, one clone was selected from each OTU for phylogenetic analysis and the total number of clones grouped to that OTU was listed after the clone name. The bootstraps (based on 1,000 replications) larger than $60 \%$ were indicated by the black dots

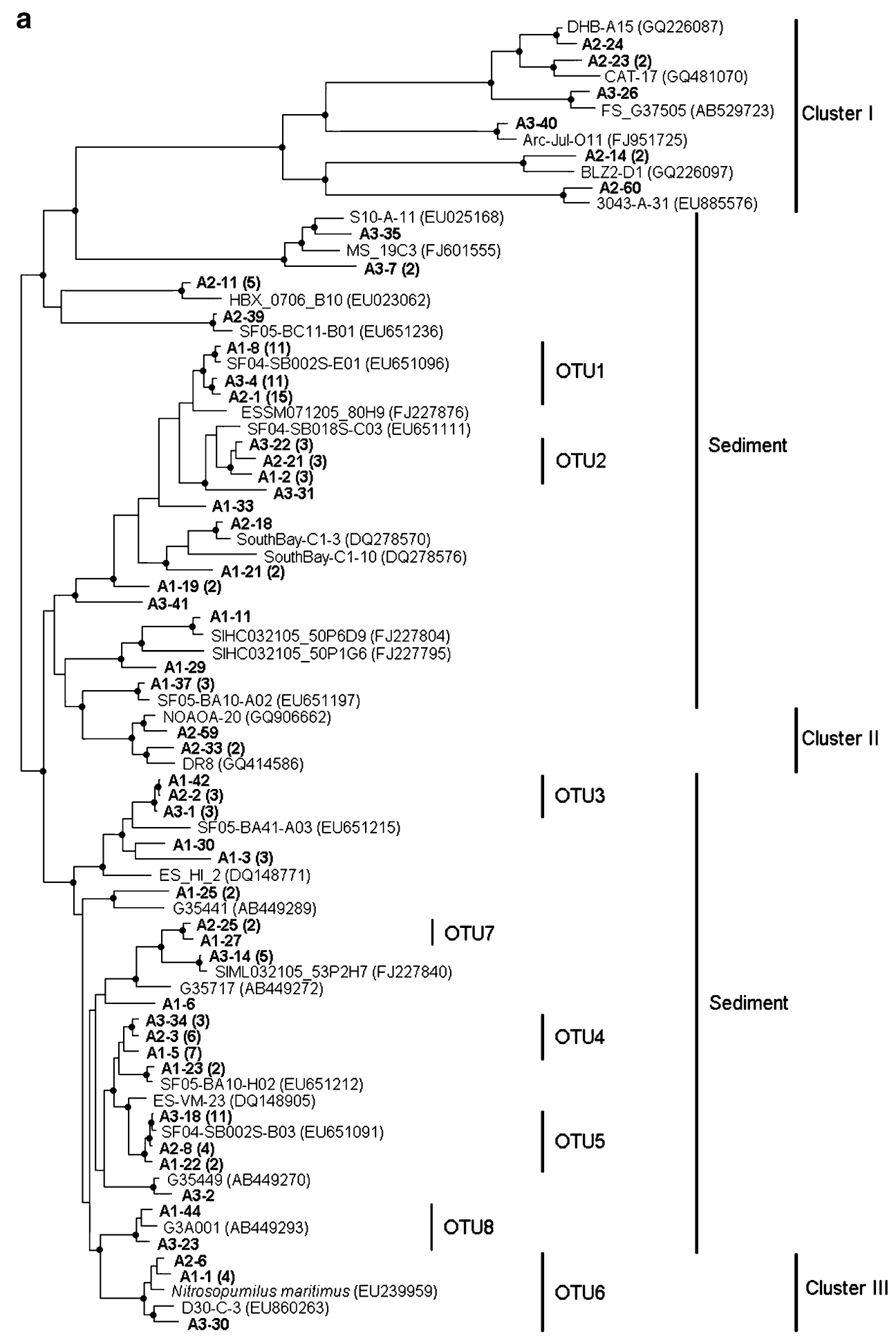

copy of $16 \mathrm{~S}$ rRNA gene per cell for both Nitrospira and Nitrosomonas (Dionisi et al. 2002), the mixed AOB community in this study should contain one copy $16 \mathrm{~S}$ rRNA gene per cell, according to the clone library results. Assuming that there are 2.5 copies of amoA gene per AOB cell (Norton et al. 2002), thus the copy number of AOB amoA gene in one sample should be 2.5 times that of $\mathrm{AOB}$ $16 \mathrm{~S}$ rRNA gene. For five sites, the average copy numbers per gram of sediment were $2.9 \times 10^{5}$ and $1.2 \times 10^{5}$ for AOB and $16 \mathrm{~S}$ rRNA gene, respectively. The results of cells of 
Fig. 2 (continued)

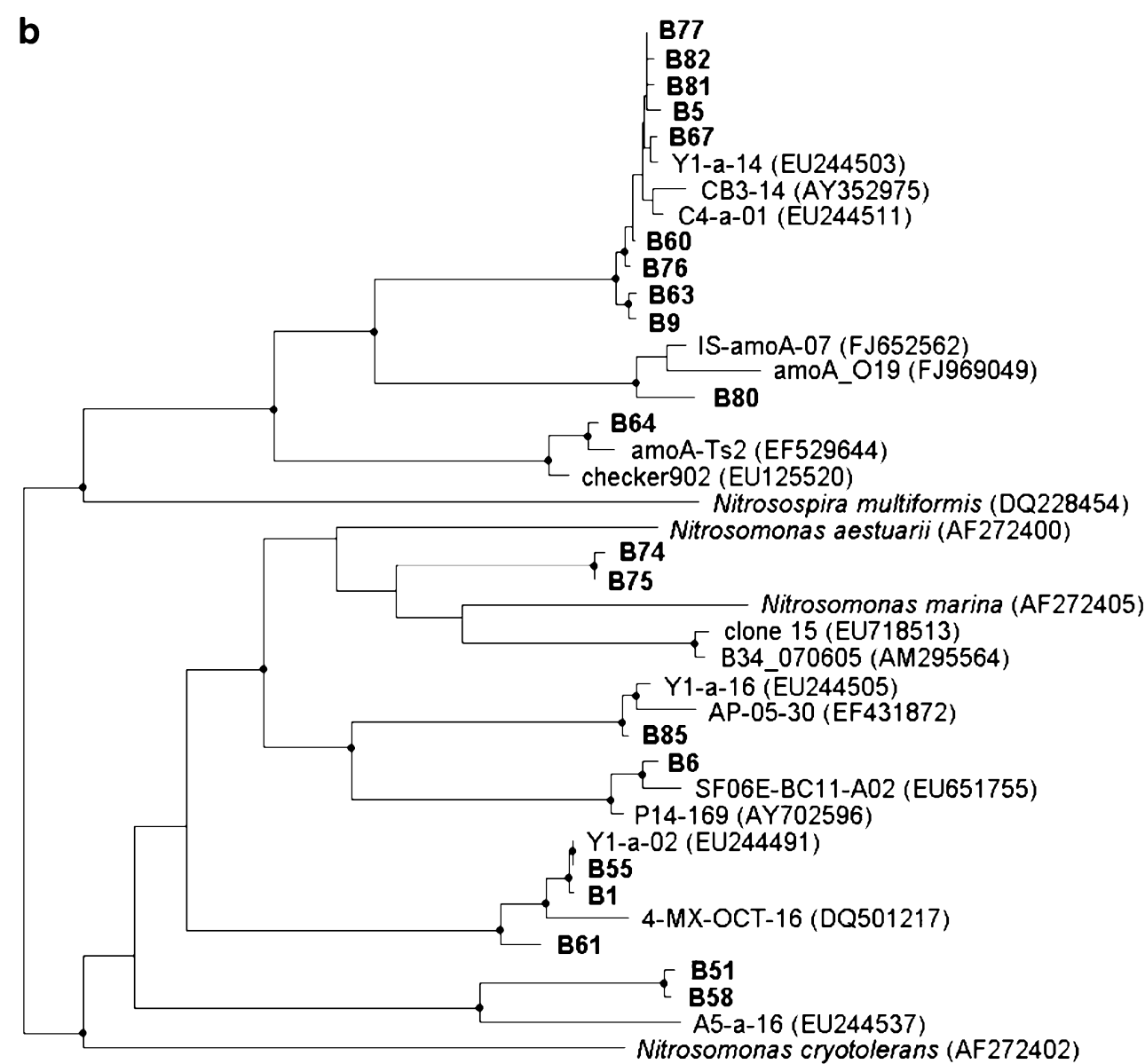

$\underline{0.01}$

AOB based on amoA gene copy number were generally consistent with those based on 16S rRNA gene (Fig. 3).

Dynamic shift of AOB community

T-RFLP analysis clearly showed the dynamic changes of AOB community among five sampling sites. There were total of four T-RFs appearing in profiles. Based on the relative abundance of each one, T-RFs of 95 and $264 \mathrm{bp}$ represented the dominant AOB and other two T-RFs of 143 and 486 bp only occupied very low abundance, less than $6 \%$ individually. All the four T-RFs could be correlated to the clones of AOB amoA gene clone library, as shown in Table S3. The T-RF of 95 bp corresponded to AOB in the genus Nitrosomonas, while T-RF of 264 bp was mainly derived from AOB in the genus Nitrosospira, although several Nitrosomonas clones also resulted in this T-RF. The clone library was constructed using the sediment sample S16, and here, it was assumed that the same T-RFs in other four samples represented similar AOB species as in the sample S16. Obviously, as shown in Fig. 4, the species compositions of AOB among five samples were dramatically different. Gradient changes showed along the sample collection sites. From the sites S4 to S21, the relative abundance of Nitrosomonas, indicated by T-RF of $95 \mathrm{bp}$, gradually decreased from $58 \%$ to the level under detection by T-RFLP. In contrast, the relative abundance of AOB in the genus Nitrosospira, indicated by T-RF of 264 bp, significantly increased to double. It was also possible that the same T-RF in different samples came from different AOB species, or the T-RF of $264 \mathrm{bp}$ in other samples was composed by AOB in two genera in different ratios, thus, in fact the diversity changes of $\mathrm{AOB}$ community among the sampling sites should be even more complicated than that observed here.

\section{Discussion}

Diversity of AOA and AOB

Phylogenetic analysis indicated that most of AOA amoA gene sequences in this study were closely related to uncultured sediment AOA found at other places, except 


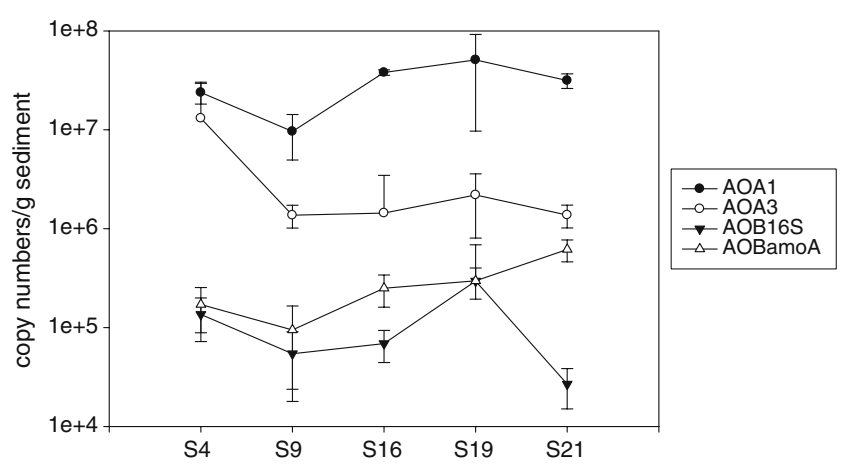

Fig. 3 Abundance of AOA amoA, AOB amoA, AOB 16S rRNA genes in the sediments of the Pearl River Estuary. qPCR was performed with three replicates for each sample. For AOA amoA gene, qPCR was conducted using FailSafe ${ }^{\mathrm{TM}}$ PCR Premix F and $0.5 \times \mathrm{SYBR}^{\circledR}$ Green I (Invitrogen, Eugene, USA). For AOB 16S rRNA and amoA genes, PCR was performed using $\mathrm{iQ}^{\mathrm{TM}} \mathrm{SYBR}^{\circledR}$ Green Super Mix. The qPCR thermocycling steps were set as follows: $95^{\circ} \mathrm{C}$ for 4 min and 45 cycles at $95^{\circ} \mathrm{C}$ for $45 \mathrm{~s}, 55^{\circ} \mathrm{C}$ for $45 \mathrm{~s}$, and $72^{\circ} \mathrm{C}$ for $45 \mathrm{~s}$. After qPCR assay, the specificity of amplification was verified by melting curve analysis and checking with agarose gel electrophoresis

three small clusters (clusters I, II, and III). Clusters I and III were grouped with sequences from mixed environmental samples, including soil (AB529723, GQ481040), hot spring (GQ226087, GQ226097), sediment (FJ951725, EU885576), active sludge of bioreactor (EU860263), and the identified pure AOA species Nitrosopumilus maritimus (EU239959). In cluster II, the two sequences were affiliated to those obtained from freshwater samples. Phylogenetic tree also showed that the most closely related sequences of five shared OTUs, except OTU6, were all from the San Francisco Bay estuary sediments (Mosier and Francis 2008). In total, these five OTUs reached $57.2 \%$ abundance (83 out of 145 clones) in the sediment of this study. These results indicated that the AOA represented by OTU1 to OTU5 in this study, and their relatives from other estuaries were possibly major AOA population in the estuary sediments, although so far, these AOA are still quite difficult to be cultured and identified. Among them, OTU1 represented the most dominant AOA group in this study, occupying $25.5 \%$ relative abundance (37 of 145 clones).

For $\mathrm{AOB}$, generally, the results from two clone libraries were comparable and consistent. It was also consistent with previous reports that $\mathrm{AOB}$ in two genera Nitrosomonas and Nitrosospira were the dominant $\mathrm{AOB}$ in estuarine sediments (Mosier and Francis 2008). Compared to AOA amoA gene, AOB showed lower diversity for the same sample in this study.

\section{Abundance of $\mathrm{AOA}$ and $\mathrm{AOB}$}

The clone library and agarose gel electrophoresis results indicated that both primer sets did not generated unspecific PCR products; thus, it seems that the real-time PCR results from primer set I should be more accurate than that from primer set III. The difference might be due to the different binding efficiencies of the two forward primers to DNA templates as the reverse primers are the same. So far, quantification of amoA gene abundance using qPCR is still in a relatively early stage of development, and more reliable measurement methods must be applied to confirm the previous findings.

Compared with the results of Mosier and Francis (2008), the AOA abundance in this study was at the high end of that in San Francisco Bay estuary sediments (from $1.4 \times 10^{4}$ to $3.9 \times 10^{7}$ copies per gram of sediment). However, in their study, high AOA abundance only occurred in low-salinity regions $(0.2-9 \mathrm{psu})$. The salinities of five sampling sites in this study increased from 5.6 to 24.6 psu, while the AOA abundance kept at high level along the salinity gradient. It might due to the high ammonia concentrations at these sites. These results also provide the possible reason for the previous report of high nitrification rates in summer at the Pearl River Estuary (Dai et al. 2008).

It was reported that $\mathrm{AOB}$ abundance increased with salinity (Mosier and Francis 2008). However, in this study, the results did not show the same relationship. Overall, AOB amoA gene copy number was 100 times lower than that of AOA, suggesting that the dominant ammonia-oxidizing microorganisms in the sediment of the Pearl River Estuary were AOA.

\section{Dynamic shift of AOB community}

Comparing the environmental parameters of five sites, the salinity ranged from 5.6 to $24.6 \mathrm{psu}$, which possibly was the key factor shaping the AOB community composition, although total abundance of AOB did not show significant fluctuation. The results indicated that $\mathrm{AOB}$ in the genus

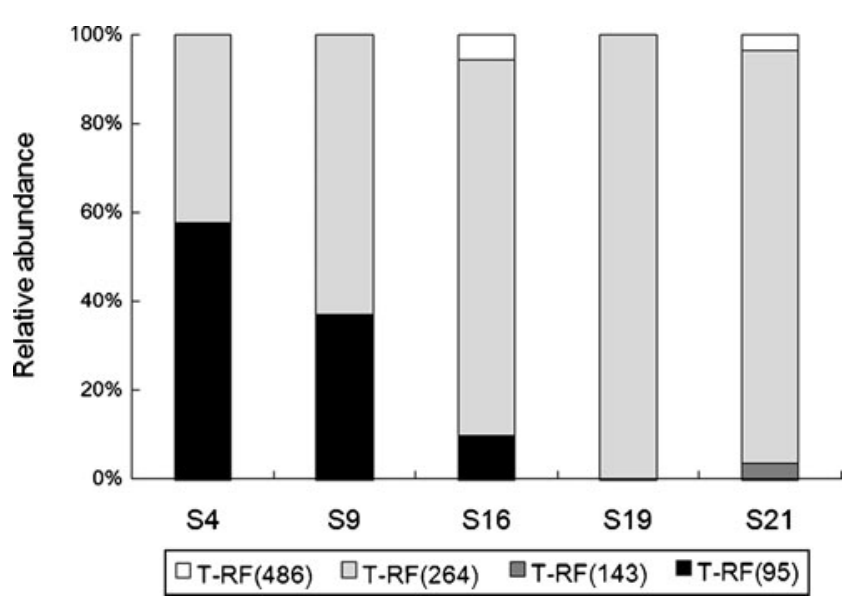

Fig. 4 Relative abundance of AOB T-RFs in the Pearl River Estuary sediments, determined by the corresponding normalized T-RFLP peak area. PCR was performed by using fluorescently labeled primer amoA-2R-Hex for AOB. PCR products were digested using AluI. The relative abundance of the selected T-RF peak (intensity above 100) was determined by calculating the ratio of its area and the total area of all selected peaks in one sample 
Nitrosomonas in this study might prefer low salinity, while in high salinity, the species in Nitrosospira were the dominant AOB. It was consistent with the previous findings in the Chesapeake Bay (Francis et al. 2003), Plum Island Sound (Bernhard et al. 2005), Ythan (Scotland) estuaries (Freitag et al. 2006), and the San Francisco Bay estuary (Mosier and Francis 2008), where similar distribution patterns of AOB in two genera were reported.

T-RFLP analysis was also applied to investigate the dynamic shift of AOA community. However, it was found that there were only three major peaks in the profiles (Fig. S3). The number of T-RFs was largely smaller than that of OTUs in AOA clone library. It means the resolution of the method was too low. The sequences of AOA amoA gene obtained in this study were aligned and virtually digested by over twenty restricted enzymes. But, there was not any enzyme which separated these sequences very well. It was concluded that T-RFLP was not a suitable method to analyze the difference of AOA community in this study.

\section{Selection of primers for AOA amoA gene}

Junier et al. (2010) summarized all the published primer sets for AOA amoA gene amplification. The primer selection is a key step for microbial community study based on PCR. However, the specificity and sensitivity of these primers were not compared so far.

In this study, three primer sets for AOA amoA gene were selected for comparison. The results of clone libraries showed that both shared and distinct clones were recovered by using different primer sets. Generally, by using any one of three primer sets, the dominant AOA species in this sediment sample, represented by the shared six OTUs, could be recovered from the clone library. However, those distinct OTUs might be recovered only by specific primers. Specially, the sequences in cluster I were only amplified by primer sets II and III. Of course, the difference among three clone libraries was also possibly due to the low abundance of those OTUs and insufficient coverage of the clone library.

Comparison of Chao 1 among three clone libraries showed that the primer set III resulted in the highest value and significantly higher than the primer set II, indicating that the primer set III might match more AOA amoA gene sequences than other two primer sets. Theoretically, using this primer set III may recover the highest diversity of AOA amoA genes in this sediment sample, although we got the highest number of OTU from clone library by using primer set I. The significant difference was also shown when primer sets were applied in qPCR. Our previous AOA study in activated sludge already reported that two primer sets showed impact in clone library results (Zhang et al. 2009). These results suggested that two or more primer sets should be tried when starting the PCR for a new environment sample. It was also indicated that the primer selection was critical for clone library construction, qPCR, and other methods based on PCR.

Acknowledgement The authors wish to thank the Hong Kong General Research Fund (HKU7197/08E) for the financial support of this study, and Lin Ye wish to thank HKU for the postgraduate studentship. This work was partially supported by the CAS/SAFEA International Partnership Program for Creative Research Teams to PY Qian.

Open Access This article is distributed under the terms of the Creative Commons Attribution Noncommercial License which permits any noncommercial use, distribution, and reproduction in any medium, provided the original author(s) and source are credited.

\section{References}

APHA (2005) Standard methods for the examination of water and wastewater, 21st edn. American Public Health Association, Washington

Beman JM, Francis CA (2006) Diversity of ammonia-oxidizing archaea and bacteria in the sediments of a hypernutrified subtropical estuary: Bahiadel Tobari. Mexico Appl Environ Microbiol 72:7767-7777

Bernhard AE, Donn T, Giblin AE, Stahl DA (2005) Loss of diversity of ammonia-oxidizing bacteria correlates within creasing salinity in an estuary system. Environ Microbiol 7:1289-1297

Dai M, Wang L, Guo X, Zhai W, Li Q, He B, Kao SJ (2008) Nitrification and inorganic nitrogen distribution in a large perturbed river/estuarine system: the Pearl River Estuary, China. Biogeosciences Discuss 5:1545-1585

De la Torre JR, Walker CB, Ingalls AE, Könneke M, Stahl DA (2008) Cultivation of a thermophilic ammonia oxidizing archaeon synthesizing crenarchaeol. Environ Microbiol 10:810-818

Dionisi HM, Layton AC, Harms G, Gregory IR, Robinson KG, Sayler GS (2002) Quantification of Nitrosomonas oligotropha-like ammonia-oxidizing bacteria and Nitrospira spp. from full-scale wastewater treatment plants by competitive PCR. Appl Environ Microbiol 68:245-253

Francis CA, O'Mullan GD, Ward BB (2003) Diversity of ammonia monooxygenase $(a m o A)$ genes across environmental gradients in Chesapeake Bay sediments. Geobiology 1:129-140

Francis CA, Roberts KJ, Beman JM, Santoro AE, Oakley BB (2005) Ubiquity and diversity of ammonia-oxidizing archaea in water columns and sediments of the ocean. Proc Natl Acad Sci USA 102:14683-14688

Freitag TE, Chang L, Prosser JI (2006) Changes in the community structure and activity of betaproteobacterial ammonia-oxidizing sediment bacteria along a freshwater-marine gradient. Environ Microbiol 8:684-696

Good IJ (1953) The population frequencies of species and the estimation of population parameters. Biometrika 40:237-264

Gruber N, Sarmiento JL (1997) Global patterns of marine nitrogen fixation and denitrification. Glob Biogeochem Cycles 11:235-266

Hallam SJ, Mincer TJ, Schleper C, Preston CM, Roberts K, Richardson PM, Delong EF (2006) Pathways of carbon assimilation and ammonia oxidation suggested by environmental genomic analyses of marine Crenarchaeota. PLoS Biol 4:e95

Huang XP, Huang LM, Yue WZ (2003) The characteristics of nutrients and eutrophication in the Pearl River estuary, South China. Mar Pollut Bull 47:30-36 
Junier P, Molina V, Dorador C, Hadas O, Kim OS, Junier T, Witzel KP, Imhoff JF (2010) Phylogenetic and functional marker genes to study ammonia-oxidizing microorganisms (AOM) in the environment. Appl Microbiol Biotechnol 85:425-440

Klotz MG, Alzerreca J, Norton JM (1997) A gene encoding a membrane protein exists upstream of the amoA/amoB genes in ammonia-oxidizing bacteria; a third member of the amo operon? FEMS Microbiol Lett 150:65-73

Könneke M, Bernhard AE, de la Torre JR, Walker CB, Waterbury JB, Stahl DA (2005) Isolation of an autotrophic ammonia-oxidizing marine archaeon. Nature 437:543-546

Kowalchuck GA, Stephen JR, De Boer W, Prosser JI, Embley TM, Woldendorp JM (1997) Analysis of ammonia-oxidizing bacteria of the $\beta$ subdivision of the class proteobacteria in costal sand dunes by denaturing gradient gel electrophoresis and sequencing of PCR-amplified 16 S ribosomal DNA fragments. Appl Environ Microbiol 63:1489-1497

Ludwig W, Strunk O, Westram R, Richter L, Meier H, Yadhukumar BA, Lai T, Steppi S, Jobb G, Forster W, Brettske I, Gerber S, Ginhart AW, Gross O, Grumann S, Hermann S, Jost R, Konig A, Liss T, Lussmann R, May M, Nonhoff B, Reichel B, Strehlow R, Stamatakis A, Stuckmann N, Vilbig A, Lenke M, Ludwig T, Bode A, Schleifer KH (2004) ARB: a software environment for sequence data. Nucleic Acids Res 32:1363-1371

Mosier AC, Francis CA (2008) Relative abundance and diversity of ammonia-oxidizing archaea and bacteria in San Francisco Bay estuary. Environ Microbiol 10:3002-3016

Norton JM, Alzerreca JJ, Suwa Y, Klotz MG (2002) Diversity of ammonia monooxygenase operon in autotrophic ammonia-oxidizing bacteria. Arch Microbiol 177:139-149

Purkhold U, Pommerening-Röser A, Juretschko S, Schmid MC, Koops HP, Wagner M (2000) Phylogeny of all recognized species of ammonia oxidizers based on comparative $16 \mathrm{~S}$ rRNA and amoA sequence analysis: implications for molecular diversity surveys. Appl Environ Microbiol 66:5368-5382

Rotthauwe JH, Witzel KP, Liesack W (1997) The ammonia monooxygenase structural gene amoA as a functional marker: molecular fine-scale analysis of natural ammonia-oxidizing populations. Appl Environ Microbiol 63:4704-4712

Sahan E, Muyzer G (2008) Diversity and spatio-temporal distribution of ammonia-oxidizing Archaea and Bacteria in sediments of the Westerschelde estuary. FEMS Microbiol Ecol 64:175-186

Seitzinger S (1988) Denitrification in fresh water and coastal marine ecosystems: ecological and geochemical significance. Limnol Oceanogr 33:702-724

Venter JC, Remington K, Heidelberg JF, Halpern AL, Rusch D, Eisen JA, Wu D, Paulsen I, Nelson KE, Nelson W, Fouts DE, Levy S, Knap AH, Lomas MW, Nealson K, White O, Peterson J, Hoffman J, Parsons R, Baden-Tillson H, Pfannkoch C, Rogers YH, Smith HO (2004) Environmental genome shotgun sequencing of the Sargasso Sea. Science 304:66-74

Voytek MA, Ward BB (1995) Detection of ammonium-oxidizing bacteria of the beta-subclass of the class Proteobacteria in aquatic samples with the PCR. Appl Environ Microbiol 61:14441450

Whitman WB, Coleman DC, Wiebe WJ (1998) Prokaryotes: the unseen majority. Proc Natl Acad Sci USA 95:6578-6583

Wuchter C, Abbas B, Coolen MJL, Herfort L, van Bleijswijk J, Timmers P, Strous M, Teira E, Herndl GJ, Middelburg JJ, Schouten S, Sinninghe Damste JS (2006) Archaeal nitrification in the ocean. Proc Natl Acad Sci USA 103:12317-12322

Zhang T, Jin T, Yan QM, Shao MF, Wells G, Criddle C, Fang HHP (2009) Occurrence of ammonia-oxidizing archaea (AOA) inactivated sludges of a laboratory scale reactor and two wastewater treatment plants. J Appl Microbiol 107:970 977 